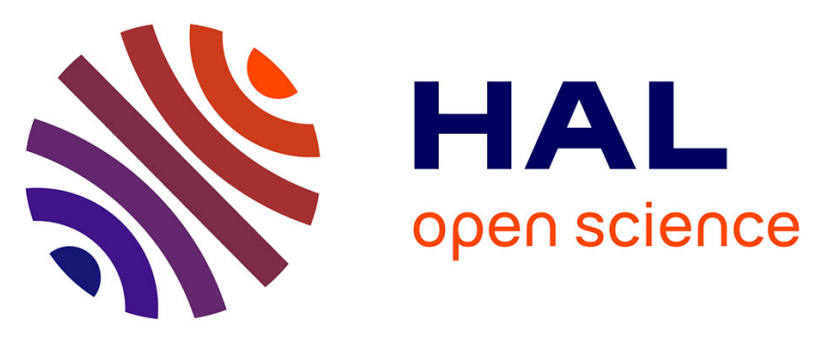

\title{
Study of aluminium oxide thin films deposited by plasma-enhanced atomic layer deposition from tri-methyl-aluminium and dioxygen precursors: investigation of interfacial and structural properties
}

Ahmet Lale, Emmanuel Scheid, Fuccio Cristiano, Lucien Datas, Benjamin Reig, Jérôme Launay, Pierre Temple-Boyer

\section{To cite this version:}

Ahmet Lale, Emmanuel Scheid, Fuccio Cristiano, Lucien Datas, Benjamin Reig, et al.. Study of aluminium oxide thin films deposited by plasma-enhanced atomic layer deposition from tri-methylaluminium and dioxygen precursors: investigation of interfacial and structural properties. Thin Solid Films, 2018, 666, pp.20 - 27. 10.1016/j.tsf.2018.09.028 . hal-02043421

\author{
HAL Id: hal-02043421 \\ https://hal.laas.fr/hal-02043421
}

Submitted on 21 Feb 2019

HAL is a multi-disciplinary open access archive for the deposit and dissemination of scientific research documents, whether they are published or not. The documents may come from teaching and research institutions in France or abroad, or from public or private research centers.
L'archive ouverte pluridisciplinaire HAL, est destinée au dépôt et à la diffusion de documents scientifiques de niveau recherche, publiés ou non, émanant des établissements d'enseignement et de recherche français ou étrangers, des laboratoires publics ou privés. 


\title{
Study of aluminium oxide thin films deposited by plasma-enhanced atomic layer deposition from tri-methyl-aluminium and dioxygen precursors: investigation of interfacial and structural properties
}

\author{
A. Lale ${ }^{1,2}$, E. Scheid ${ }^{1,2}$, F. Cristiano ${ }^{1,2}$, L. Datas ${ }^{3}$, B. Reig ${ }^{1,2}$, J. Launay ${ }^{1,2}$, Pierre Temple-Boyer ${ }^{1,2}$ \\ ${ }^{1}$ CNRS, LAAS, 7 avenue du colonel Roche, F-31400 Toulouse, France \\ ${ }^{2}$ Université de Toulouse, UPS, LAAS, F-31400 Toulouse, France \\ ${ }^{3}$ Université de Toulouse, Centre de microcaractérisation Raimond Castaing, F-31400 Toulouse, France
}

\begin{abstract}
:
Aluminium oxide $\left(\mathrm{Al}_{2} \mathrm{O}_{3}\right)$ films were deposited on silicon substrates using plasma-enhanced atomic layer deposition (PE-ALD) technique with tri-methyl-aluminium TMA $\left(\mathrm{Al}\left(\mathrm{CH}_{3}\right)_{3}\right)$ and dioxygen $\left(\mathrm{O}_{2}\right)$ as precursors. PE-ALD experiments were performed in order to (i) investigate the interfacial properties between the silicon substrate and the alumina layer, and (ii) understand the impact of growth and crystallization phenomena on the $\mathrm{Al}_{2} \mathrm{O}_{3}$ films properties (structural, optical, mechanical, dielectric and etch). The formation of oxide-based transition layers, either silicon oxide $\mathrm{SiO}_{2}$ and/or aluminosilicate $\mathrm{Al}_{\mathrm{x}} \mathrm{Si}_{\mathrm{y}} \mathrm{O}$, was evidenced for the TMA/O $\mathrm{PE}-\mathrm{ALD}$ process. Based on these results, it appears that no substrate-enhanced growth occurs at the early stages of the growth process, as assumed in previous reports. Thus, constant growth rate $(0.08 \mathrm{~nm}$ per cycle $)$ and refractive index (1.64 at a $450 \mathrm{~nm}$ wavelength) were obtained for the $\mathrm{Al}_{2} \mathrm{O}_{3}$ layer deposited at $300^{\circ} \mathrm{C}$. Finally, thermal annealing experiments were performed on these films, evidencing the influences of atomic structural rearrangement and crystallization on the $\mathrm{Al}_{2} \mathrm{O}_{3}$ film main characteristics: interface steepness, atomic structure, refractive index, residual stress, dielectric constant and etch rate.
\end{abstract}

Keywords: Plasma-enhanced atomic layer deposition, PE-ALD, Thin film, Alumina, Aluminium oxide, $\mathrm{Al}_{2} \mathrm{O}_{3}$, Interfacial properties, Physical properties 


\section{Introduction}

In the frame of microtechnologies, aluminium oxide $\left(\mathrm{Al}_{2} \mathrm{O}_{3}\right)$ has been investigated for several applications: as a "high-k" material for MOS gate oxide [1,2], as an ion-sensitive and passivation layer for FET-based microsensors $[3,4]$, as a passivation layer for OLED and solar cell devices $[5,6]$, as a luminescent material for dosimeters [7],... As a consequence, many processes based on physical and/or chemical deposition techniques were developed in order to integrate alumina thin films with optimized properties into the corresponding fabrication processes: electron beam evaporation [8,9], pulsed laser deposition [10], sputtering [11], chemical vapour deposition [12], metal-organic chemical vapour deposition [13], plasma-enhanced chemical vapour deposition $[14], \ldots$ Among them, atomic layer deposition (ALD) was thoroughly studied for the conformal deposition of $\mathrm{Al}_{2} \mathrm{O}_{3}$ thin films [15-17], emphasizing the use of tri-methyl-aluminium $\mathrm{Al}\left(\mathrm{CH}_{3}\right)_{3}$ (also called TMA) as an aluminium source and water $\left(\mathrm{H}_{2} \mathrm{O}\right)$ as an oxidant source [18-25]. Nevertheless, other sources such aluminium trichloride $\left(\mathrm{AlCl}_{3}\right)$ as well as dioxygen $\left(\mathrm{O}_{2}\right)$ and ozone $\left(\mathrm{O}_{3}\right)$, were also developed in parallel using plasma-enhanced atomic layer deposition (PE-ALD) in order to reduce the impurity content in the grown $\mathrm{Al}_{2} \mathrm{O}_{3}$ film and improve their dielectric properties [24-28].

In the different studies related to the ALD process [18-28], the presence of a steep interface was systematically assumed between the $\mathrm{Al}_{2} \mathrm{O}_{3}$ films and the silicon substrate, which allows simplifying the determination of the ALD growth rate per cycle as well as defining different growth types: linear, substrate-enhanced and substrate-inhibited [29]. This "steep interface" assumption seems obvious when considering the atomic layer deposition principles. Nevertheless, since other physical and chemical phenomena occur during the ALD process, it seems crucial to investigate the ALD film layer structure in more detail [30]. This paper proposes, firstly, to investigate the interfacial properties between the silicon substrate and PE-ALD alumina thin films deposited from 
$\mathrm{Al}\left(\mathrm{CH}_{3}\right)_{3} / \mathrm{O}_{2}$ precursors, and, secondly, to study the structural, optical, mechanical and dielectric properties of the grown layers, focusing on the impact of a post-growth rapid thermal anneal step (in the $500^{\circ} \mathrm{C}-1100^{\circ} \mathrm{C}$ temperature range) on their evolution.

\section{Experimental details}

Growth experiments were carried out in a FIJI F200 ALD equipment developed by CAMBRIDGE NANOTECH company. Prior to deposition, 100mm (100) silicon substrates were cleaned into diluted hydrofluoric acid $(\mathrm{HF}-10 \%)$ to remove any oxide layer. After this $\mathrm{HF}$ cleaning, the native $\mathrm{SiO}_{2}$ layer was still estimated around $0.7 \mathrm{~nm}$ by ellipsometry. Then, $\mathrm{Al}_{2} \mathrm{O}_{3}$ films were deposited using conventional experimental conditions (deposition temperature: $300^{\circ} \mathrm{C}$, base pressure: 70 mTorr) from tri-methyl-aluminium $\mathrm{Al}\left(\mathrm{CH}_{3}\right)_{3}(\mathrm{TMA})$ and dioxygen $\left(\mathrm{O}_{2}\right)$ according to a standard routine: TMA injection in gaseous phase (injection duration: $0.025 \mathrm{~s}$ ), purge (argon: $180 \mathrm{sccm}$, duration: $6 \mathrm{~s})$, plasma $\mathrm{O}_{2}$ exposure $\left(\mathrm{O}_{2}: 20 \mathrm{sccm}\right.$, plasma power: $\left.300 \mathrm{~W}\right)$, purge (argon: $180 \mathrm{sccm}$, duration: $6 \mathrm{~s}$ ). These experimental conditions and durations were chosen in order to saturate the ALD growth rate while preventing any undesirable gaseous mixing [24,25,27]. Thus, $\mathrm{Al}_{2} \mathrm{O}_{3}$ growth occurs according to the binary reaction sequence [31]:

$$
\begin{aligned}
& -\mathrm{AlOH}^{*}+\mathrm{Al}\left(\mathrm{CH}_{3}\right)_{3}---->-\mathrm{Al}-\mathrm{O}-\mathrm{Al}\left(\mathrm{CH}_{3}\right)_{2}^{*}+\mathrm{CH}_{4} \\
& -\mathrm{AlCH}_{3}^{*}+2 \mathrm{O}_{2}---->-\mathrm{AlOH}^{*}+\mathrm{CO}_{2}+\mathrm{H}_{2} \mathrm{O}
\end{aligned}
$$

where $-\mathrm{AlOH}^{*}, \quad-\mathrm{Al}-\mathrm{O}-\mathrm{Al}\left(\mathrm{CH}_{3}\right)_{2} *$ and $-\mathrm{AlCH}_{3} *$ represent surface species while monofunctional adsorption is assumed for simplification.

Thermal anneals were performed in an AnnealSys AS-Master-2000HT rapid thermal process (RTP) equipment using two different gaseous atmospheres $\left(\mathrm{N}_{2} / \mathrm{H}_{2}\right.$ or $\left.\mathrm{O}_{2}\right)$. Aluminium oxide films 
were etched using (i) phosphoric and hydrofluoric acids $\left(\mathrm{H}_{3} \mathrm{PO}_{4} 85 \%\right.$ and $\left.\mathrm{HF} 5 \%\right)$ for wet etching as well as (ii) a $\mathrm{Cl}_{2}$ dry etching gas in an ICP-RIE (Inductively coupled plasma reactive ion etching) Trikon Omega 201 equipment (ICP power: $500 \mathrm{~W}$, bias power: 25-100 W) [32].

Structural, optical, mechanical and dielectric properties of aluminium oxide thin films were studied using numerous characterisation techniques. Alumina films were studied by spectroscopic ellipsometry using an Uvisel equipment from Horiba Jobin Yvon, in order to estimate deposited thicknesses as well as optical indexes at a $450 \mathrm{~nm}$ wavelength. Growth rates per ALD cycle were finally calculated by dividing the deposited thickness by the ALD cycle number. The accuracy of these measurements was estimated to be $\pm 2 \%$.

Wafer curvature measurements before and after PE-ALD film deposition were also performed by profilometry. Since the deposited films were very thin compared to the silicon substrate (thickness: $\sim 500 \mu \mathrm{m}$ ), their residual stress was finally calculated thanks to the Stoney's formula $[33,34]$. The accuracy of the whole technique was estimated at $\pm 5 \%$.

Dielectric properties were studied using a mercury probe (MDC company, model 802C) coupled with an Agilent 4294A impedance analyser. Using a $4.18 \times 10^{-3} \mathrm{~cm}^{2}$ mercury contact area, C-V experiments were performed between $-10 \mathrm{~V}$ and $+10 \mathrm{~V}$ for a $100 \mathrm{mV}$ sinusoidal signal at 1 , 10, 100 and $1000 \mathrm{kHz}$. Thus, alumina dielectric constant was calculated from the capacitance value in accumulation thanks to the standard planar capacitor equation. The accuracy of the whole technique was estimated at $\pm 5 \%$.

TEM (Transmission electron microscopy) was performed in a TEM JEOL JEM-ARM200F cold FEG, STEM corrected, equipment installed in the French "Centre de microcaractérisation Raimond Castaing" (Toulouse, France). At $200 \mathrm{kV}$, its point-to-point resolution is $0.19 \mathrm{~nm}$ in TEM mode $(0.078 \mathrm{~nm}$ in STEM mode). It is coupled with an EDX (Energy Dispersive X-ray) spectrometer JEOL CENTURIO in order to analyse atomic compositions at the nanoscale (resolution: $2 \mathrm{~nm}$ ). Before the experiments, the EDX spectrometer was calibrated using a 
monocrystalline sapphire sample. Then, $\sim 100 \mathrm{~nm}$-thin TEM samples were prepared from $\mathrm{Al}_{2} \mathrm{O}_{3}$ films using a FEI Helios 600i FIB (Focused Ion Beam) equipment. GIXRD (Grazing Incidence Xray Diffraction) experiments were also performed using a Bruker D8 Discovery diffractometer (Xray source and associated wavelength: $\mathrm{K} \alpha 1$ copper, $0.154056 \mathrm{~nm}$ ) in order to study alumina film crystallinity.

\section{Results and discussion}

\subsection{Mean growth rate per ALD cycle and refractive index}

Alumina films characteristics were studied by spectroscopic ellipsometry taking into account the $0.7 \mathrm{~nm}$ native silicon oxide layer present after HF clean. Thus, assuming steep interfaces for the $\mathrm{Si} / \mathrm{SiO}_{2} / \mathrm{Al}_{2} \mathrm{O}_{3}$ structure, the deposited thickness, i.e. the mean growth rate per ALD cycle $\mathrm{g}_{\mathrm{r}}$, as well as the refractive index at a $450 \mathrm{~nm}$ wavelength $\mathrm{n} 450 \mathrm{~nm}$ were estimated (figure 1). From these first results, the studied $\mathrm{TMA} / \mathrm{O}_{2} \mathrm{PE}-\mathrm{ALD}$ process appears to be characterized by a substrate-enhanced growth [29] with an apparent $\mathrm{g}_{\mathrm{r}}$ value around $0.09 \pm 0.01 \mathrm{~nm}$ for the highest number of ALD cycles. Nevertheless, the associated refractive index variations are quite surprising since the $\mathrm{n}_{450 \mathrm{~nm}}$ apparent value increases from 1.47 (i.e. similar to silicon dioxide $\mathrm{SiO}_{2}$ ) at the early stages of the growth, up to 1.67 for the highest number of cycles, i.e. far lower than the value known for bulk monocrystalline alumina or sapphire: $\mathrm{n}_{450 \mathrm{~nm}}=1.78[35]$.

In order to check the steepness of the different interfaces and to have a better analysis of these results, TMA/O ${ }_{2}$ samples were characterized by TEM coupled with EDX spectrometry. For the thinnest samples (number of cycles: 30 and 60), investigations evidenced a thickness increase of the initial native oxide layer $(0.7 \mathrm{~nm})$, accompanied by the formation of an $\mathrm{Al}_{x} \mathrm{Si}_{\mathrm{y}} \mathrm{O}$ aluminosilicate overlayer (figures $2 \mathrm{a}$ and $2 \mathrm{~b}$ ). On the contrary, for the thickest samples (number of cycles: 300 and 600) no $\mathrm{SiO}_{2}$ layer is observed. Instead, an $\mathrm{Al}_{\mathrm{x}} \mathrm{Si}_{\mathrm{y}} \mathrm{O} / \mathrm{Al}_{2} \mathrm{O}_{3}$ structure is formed (figures $3 \mathrm{a}$ and $3 \mathrm{~b}$ ). 
The different transition layers (cf. dashed lines in figures $2 \mathrm{~b}$ and $3 \mathrm{~b}$ ) are determined from the variation of the atomic profiles extracted from the intensity of the different EDX peaks (arbitrary units). In the case of the upper alumina layer in samples with a high number of cycles, it was possible to quantify the EDX spectra and confirm the effective deposition of a stoichiometric $\mathrm{Al}_{2} \mathrm{O}_{3}$ alumina layer. The mean values of the different layer thicknesses are given in table 1 .

According to these results, it appears that, for ALD cycle number lower than 100 (i.e. for film thickness lower than $10 \mathrm{~nm}$ ), silicon oxidation occurs during the "TMA injection - plasma $\mathrm{O}_{2}$ " routine. Since only native oxide is present on the silicon substrate, this phenomenon is responsible for the growth of the underlayer oxide layer. Moreover, rather than an alumina $\mathrm{Al}_{2} \mathrm{O}_{3}$ film, an aluminosilicate $\mathrm{Al}_{x} \mathrm{Si}_{\mathrm{y}} \mathrm{O}$ one is simultaneously formed on top, leading to the formation of a $\mathrm{SiO}_{2} / \mathrm{Al}_{x} \mathrm{Si}_{y} \mathrm{O}$ structure. On the contrary, for ALD cycle number higher than 200 (i.e. for film thickness higher than $20 \mathrm{~nm}$ ), the TMA/O 2 PE-ALD routine is efficient and allows to effectively deposit alumina atomic layers on top, leading to a final $\mathrm{Al}_{\mathrm{x}} \mathrm{Si}_{\mathrm{y}} \mathrm{O} / \mathrm{Al}_{2} \mathrm{O}_{3}$ structure.

Such experiments clearly show that silicon oxidation and the associated diffusion phenomena interfere with the TMA/O 2 PE-ALD process. This scenario was confirmed by studying a 300 -cycle PE-ALD films deposited on top of a thermally oxidized silicon substrate $\left(\mathrm{SiO}_{2}\right.$ thickness: $\sim 10 \mathrm{~nm}$, cf. table 1 , bottom row). In this case, considering the TEM/EDX resolution ( $2 \mathrm{~nm})$, no aluminosilicate layer was evidenced and only alumina was effectively deposited, leading to a final $\mathrm{SiO}_{2} / \mathrm{Al}_{2} \mathrm{O}_{3}$ structure with steep interfaces (figure 4). Such result is consistent with the interference of silicon oxidation during the first ALD cycles: the thicker the oxide underlayer, the less effective the silicon oxidation phenomenon will be, resulting in a thinner aluminosilicate intermediate layer.

As a matter of fact, it finally appears that the initial $\mathrm{SiO}_{2} / \mathrm{Al}_{\mathrm{x}} \mathrm{Si}_{\mathrm{y}} \mathrm{O}$ bilayer transforms into an aluminosilicate monolayer prior to forming the final $\mathrm{Al}_{x} \mathrm{Si}_{\mathrm{y}} \mathrm{O} / \mathrm{Al}_{2} \mathrm{O}_{3}$ structure. Such transition is expected to be controlled by the diffusion of oxygen, aluminium and silicon atoms during the PEALD process (performed at $300^{\circ} \mathrm{C}$ ), as already shown for hafnium oxide thin films deposited by 
ALD [36]. In order to check this assumption, the 600-cycle $\mathrm{Al}_{x} \mathrm{Si}_{y} \mathrm{O} / \mathrm{Al}_{2} \mathrm{O}_{3}$ film was annealed for 5 minutes under an $\mathrm{O}_{2}$ gaseous atmosphere at different temperatures $\left(750^{\circ} \mathrm{C}\right.$ and $\left.900^{\circ} \mathrm{C}\right)$. Indeed, TEM/EDX characterizations showed that the aluminosilicate $\mathrm{Al}_{\mathrm{x}} \mathrm{Si}_{\mathrm{y}} \mathrm{O}$ underlayer broke up in order to participate to the formation of both $\mathrm{SiO}_{2}$ lower layer and $\mathrm{Al}_{2} \mathrm{O}_{3}$ upper layer (table 2 and figure 5). Thus, the thermal diffusion and rearrangement of oxygen, aluminium and silicon atoms into a $\mathrm{Si} / \mathrm{SiO}_{2} / \mathrm{Al}_{2} \mathrm{O}_{3}$ structure with steep interfaces was effectively demonstrated.

In view of these results, the values of film deposited thickness and refractive index, initially determined by spectroscopic ellipsometry, were reconsidered assuming the formation of a $\mathrm{SiO}_{2} / \mathrm{Al}_{\mathrm{x}} \mathrm{Si}_{\mathrm{y}} \mathrm{O} / \mathrm{Al}_{2} \mathrm{O}_{3}$ structure in all samples, independently of the number of PE-ALD cycles. Thus, in all cases, the refractive index at a $450 \mathrm{~nm}$ wavelength $\mathrm{n}_{450 \mathrm{~nm}}$ of the $\mathrm{Al}_{2} \mathrm{O}_{3}$ upper layer was estimated around 1.64. In parallel, the mean growth rate per ALD cycle $\mathrm{g}_{\mathrm{r}}$ was finally estimated around $0.08 \pm 0.005 \mathrm{~nm}$ whatever the number of ALD cycles.

Thus, it is finally shown that the TMA/O 2 PE-ALD process is not characterized by steep interfaces. For low ALD cycle numbers (lower than 100), the "TMA injection - plasma $\mathrm{O}_{2}$ " routine is responsible for the silicon substrate oxidation, i.e. for the growth of a $\mathrm{SiO}_{2}$ underlayer, and, subsequently, for the deposition of an $\mathrm{Al}_{x} \mathrm{Si}_{y} \mathrm{O}$ aluminosilicate film. Taking into account this phenomenon, it is clear that no substrate-enhanced growth occurs at the early stages of the growth process, as previously assumed. Indeed, apart for the initial regime, the TMA/O 2 PE-ALD process occurs in a standard way, allowing the deposition of stoichiometric alumina $\mathrm{Al}_{2} \mathrm{O}_{3}$ with a linear growth mechanism, i.e. with a constant growth rate.

In the following, investigations will focus on the physical/chemical properties of TMA/O 2 PEALD films obtained for high numbers of ALD cycles (higher than 400). For such high ALD cycle numbers, the influence of the aluminosilicate $\mathrm{Al}_{\mathrm{x}} \mathrm{Si}_{\mathrm{y}} \mathrm{O}$ lower layer is negligible (figure 1), allowing to consider a global $\mathrm{SiO}_{2} / \mathrm{Al}_{2} \mathrm{O}_{3}$ structure. According to our analyses, this assumption is related to 
measurement errors around $\pm 4 \%$ for the alumina film thickness and related parameters (see hereafter).

\subsection{Thermal annealing influences}

Since as-deposited alumina films were characterized by refractive index lower than expected, the influence of thermal annealing was investigated in detail. Thus, different rapid thermal annealing processes (duration: 5 minutes, gaseous atmospheres: $\mathrm{N}_{2} / \mathrm{H}_{2}$ and $\mathrm{O}_{2}$ ) were performed at increasing temperatures, i.e. from 500 to $1100^{\circ} \mathrm{C}$, on different 400 -cycle alumina samples. In both gaseous ambiences, the refractive index at a 450nm wavelength was found to increase with annealing temperature (figure 6). Starting at $750^{\circ} \mathrm{C}$ from the as-deposited $\mathrm{n}_{450 \mathrm{~nm}}$ value around 1.64 , a sigmoidal variation was evidenced to reach a final $\mathrm{n}_{450 \mathrm{~nm}}$ value around 1.72 . Since such variations were already evidenced for ALD alumina films [37] and associated to crystallization phenomena for CVD silicon film [34], X-ray diffraction analysis was performed on the different samples. According to a previous study [38], XRD spectra were studied in the $\left[30^{\circ}-72^{\circ}\right] 2 \theta$ angle range and more precisely around $67.8^{\circ}$ (figures $7 \mathrm{a}$ and $7 \mathrm{~b}$ ). At this $2 \theta$ angle value, starting at $800^{\circ} \mathrm{C}$, the temperature increase is responsible for the appearance of an intensity peak that was previously related to crystallization phenomena (figures $7 \mathrm{~b}$ and $7 \mathrm{c}$ ). Thus, the refractive index $\mathrm{n}_{450 \mathrm{~nm}}$ increase with annealing temperature was effectively related to the transition from amorphous to polycrystalline alumina. As a result, the corresponding values were determined:

- PE-ALD amorphous alumina: $\mathrm{n}_{450 \mathrm{~nm}} \approx 1.64$

- PE-ALD polycrystalline alumina: $\mathrm{n}_{450 \mathrm{~nm}} \approx 1.72$

The $\mathrm{n}_{450 \mathrm{~nm}}$ value obtained for polycrystalline alumina was still lower than 1.78 , evidenced for bulk monocrystalline alumina or sapphire [35]. As already shown for monocrystalline and 
polycrystalline silicon [34], this discrepancy might be associated to the presence of amorphous grain boundaries in the polycrystalline $\mathrm{Al}_{2} \mathrm{O}_{3}$ films (figure 8).

\subsection{Residual stress}

The residual stress $\sigma$ of the different 900 -cycle $\mathrm{TMA} / \mathrm{O}_{2} \mathrm{PE}-\mathrm{ALD}$ films was studied by wafer curvature measurements and calculated using the Stoney equation while considering a $\mathrm{SiO}_{2} / \mathrm{Al}_{2} \mathrm{O}_{3}$ bilayer. Independently of the gaseous atmosphere $\left(\mathrm{N}_{2} / \mathrm{H}_{2}\right.$ and $\left.\mathrm{O}_{2}\right)$, similar variations were evidenced as a function of the annealing temperature (figure 9).

Initially, the as-deposited alumina films were characterized by a "no-stress" configuration ( $\sigma$ $\approx+10 \mathrm{MPa}$ ). Then, a first increase was evidenced between 500 and $700^{\circ} \mathrm{C}$ to reach a $+300 \mathrm{MPa}$ tensile stress. This phenomenon could be related to the diffusion of oxygen, aluminium and silicon atoms into the film occurring at such temperature and therefore associated to the rearrangement of the $\mathrm{Al}_{\mathrm{x}} \mathrm{Si}_{\mathrm{y}} \mathrm{O} / \mathrm{Al}_{2} \mathrm{O}_{3}$ structure towards the $\mathrm{SiO}_{2} / \mathrm{Al}_{2} \mathrm{O}_{3}$ one (see section 3.1 above). Then, a second sharp increase was evidenced between 750 and $800^{\circ} \mathrm{C}$ to reach very high tensile stress values $(\sigma \approx$ +2200 MPa). As shown by Krautheim et al. [39] and as seen previously (see section 3.2 above), this phenomenon should be related to film crystallization and therefore to the transition from amorphous to polycrystalline alumina. However, if a sigmoidal stress variation was expected (as shown for amorphous silicon crystallization [34]), a third phenomenon responsible for compressive stress was shown to interfere for temperature higher than $800^{\circ} \mathrm{C}$. Thus, a stress decrease was finally evidenced for the highest temperatures. This last phenomenon is not clearly explained. Since it was obtained for both gaseous atmosphere $\left(\mathrm{N}_{2} / \mathrm{H}_{2}\right.$ and $\left.\mathrm{O}_{2}\right)$, it cannot be due to silicon oxidation phenomena (negligible for stress measurement) but should be related to some phase transition into polycrystalline alumina [39].

\subsection{Dielectric constant}


The dielectric constant $\varepsilon_{\mathrm{r}}$ of different 400 -cycle TMA/O 2 PE-ALD films was studied by capacitance-voltage $(\mathrm{C}-\mathrm{V})$ measurements at different frequencies $(1,10,100$ and $1000 \mathrm{kHz})$ and analysed as a function of the annealing temperature (gaseous atmosphere: $\mathrm{O}_{2}$ ). Measured $\mathrm{C}-\mathrm{V}$ curves are characteristics of a Metal-Insulator-Silicon capacitive structure (results not shown), enabling the determination of the capacitance in accumulation $\mathrm{C}_{\text {acc }}$. Finally, the insulator equivalent dielectric constant $\varepsilon_{\mathrm{r}}$ was estimated using the planar capacitor equation while considering a $\mathrm{SiO}_{2} / \mathrm{Al}_{2} \mathrm{O}_{3}$ bilayer. As shown for the refractive index $\mathrm{n}_{450 \mathrm{~nm}}$ (see section 3.2 above), a typical sigmoidal variation was obtained, evidencing a dielectric constant increase from 8.5 to 10.2 with temperature (figure 10). Again, this variation should be related to crystallization phenomena of alumina between 750 and $850^{\circ} \mathrm{C}$. As a result, the dielectric constants of amorphous and polycrystalline alumina were determined:

- PE-ALD amorphous alumina: $\varepsilon_{\mathrm{r}} \approx 8.5$

- PE-ALD polycrystalline alumina: $\varepsilon_{\mathrm{r}} \approx 10.2$

These $\varepsilon$ values are in good agreement with standard value obtained for bulk monocrystalline alumina or sapphire [40].

\subsection{Etch properties}

Since the integration of TMA/O ${ }_{2}$-based $\mathrm{Al}_{2} \mathrm{O}_{3}$ PE-ALD films is planned for the realization of microtechnological devices, their chemical and physical etch properties were also studied (table 3). Concerning wet etching, phosphoric acid $\mathrm{H}_{3} \mathrm{PO}_{4}$ was found to be ineffective while hydrofluoric acid HF was only effective for amorphous $\mathrm{Al}_{2} \mathrm{O}_{3}$ (etch rate: $40 \mathrm{~nm} / \mathrm{min}$ ). In order to etch polycrystalline $\mathrm{Al}_{2} \mathrm{O}_{3}$, a $\mathrm{Cl}_{2}$-based dry etch in an ICP-RIE equipment was implemented. Thus, depending on the ICP power, the etch rate was found to increase linearly up to $90 \mathrm{~nm} / \mathrm{min}$ for amorphous $\mathrm{Al}_{2} \mathrm{O}_{3}$, 
while it saturates at a maximal value of $40 \mathrm{~nm} / \mathrm{min}$ for polycrystalline $\mathrm{Al}_{2} \mathrm{O}_{3}$. According to our results, a bias power of $50 \mathrm{~W}$ is proposed in order to effectively and selectively etch any $\mathrm{TMA} / \mathrm{O}_{2}$ based $\mathrm{Al}_{2} \mathrm{O}_{3}$ PE-ALD films.

\section{Conclusion}

In summary, PE-ALD $\mathrm{Al}_{2} \mathrm{O}_{3}$ thin films (thickness range: $6-72 \mathrm{~nm}$ ) were deposited on silicon substrates using TMA/O 2 precursors. TEM/EDX investigations evidenced the formation of different transition layers depending on the number of ALD cycles. For low ALD cycle numbers (lower than 100), it was demonstrated that the $\mathrm{TMA} / \mathrm{O}_{2}$ PE-ALD routine is not efficient to deposit alumina atomic layers because of silicon oxidation phenomena. As a result, the initial formation of a $\mathrm{SiO}_{2} / \mathrm{Al}_{\mathrm{x}} \mathrm{Si}_{\mathrm{y}} \mathrm{O}$ transition structure with no steep interface was shown. For high ALD cycle numbers (higher than 200), oxidation phenomena are inhibited due to the higher deposited thickness so that the TMA/O $\mathrm{O}_{2}$ PE-ALD process operates normally to form alumina layers. Nevertheless, diffusion and rearrangement of oxygen, aluminium and silicon atoms were found to interfere with the PEALD process, leading to the formation of an aluminosilicate $\mathrm{Al}_{x} \mathrm{Si}_{\mathrm{y}} \mathrm{O}$ transition layer and the deposition of a final $\mathrm{Al}_{x} \mathrm{Si}_{\mathrm{y}} \mathrm{O} / \mathrm{Al}_{2} \mathrm{O}_{3}$ stack. In view of these different mechanisms, no "substrateenhanced growth" phenomenon was finally evidenced for the TMA/O $\mathrm{O}_{2}$ PE-ALD process. As a result, a constant growth rate $(0.08 \mathrm{~nm}$ per cycle $)$ and refractive index $(1.64$ at a $450 \mathrm{~nm}$ wavelength) were obtained for the deposited $\mathrm{Al}_{2} \mathrm{O}_{3}$ upper layer, independently of the number of ALD cycles.

The influence of post-growth thermal annealing was also investigated. Thanks to XRD analysis, crystallization of $\mathrm{Al}_{2} \mathrm{O}_{3}$ films was found to start at a temperature of $750^{\circ} \mathrm{C}$. Then, thermally induced atomic rearrangement within the $\mathrm{Al}_{2} \mathrm{O}_{3}$ structure was found to be responsible for sigmoidal increases of various parameters with increasing temperature, such as the refractive index 
at a $450 \mathrm{~nm}$ wavelength $\mathrm{n}_{450 \mathrm{~nm}}$, the residual stress $\sigma$ and the dielectric constant $\varepsilon_{\mathrm{r}}$. Thus, the corresponding properties of amorphous and polycrystalline alumina were finally determined. The results obtained in this work allow to have a better understanding of the PE-ALD- $\mathrm{Al}_{2} \mathrm{O}_{3}$ film deposition process and related properties. They will be helpful for the integration of thick (> $20 \mathrm{~nm})$ alumina layers in the frame of micro/nano-technological applications.

\section{Acknowledgements}

Technological realizations were partly supported by the French RENATECH network. Furthermore, we would like to thank Vincent Mortet (Institute of physics, Academy of sciences of the Czech Republic) for helpful discussions.

\section{References}

[1] R.M. Wallace and G.D. Wilk, "High-k dielectric materials for microelectronics", Critical Reviews in Solid State and Materials Sciences, 28 (2003) 231-285

[2] J.A. Kittl, K. Opsomer, M. Popovici, N. Menou, B. Kaczer, X.P. Wang, C. Adelmann, M.A. Pawlak, K. Tomida, A. Rothschild, B. Govoreanu, R. Degraeve, M. Schaekers, M. Zahid, A. Delabie, J. Meersschaut, W. Polspoel, S. Clima, G. Pourtois, W. Knaepen, C. Detavernier, V.V. Afanas'ev, T. Blomberg, D. Pierreux, J. Swerts, P. Fischer, J.W. Maes, D. Manger, W. Vandervorst, T. Conard, A. Franquet, P. Favia, H. Bender, B. Brijs, S. Van Elshocht, M. Jurczak, J. Van Houdt, D.J. Wouters, "high-k dielectrics for future generation memory devices", Microelectronic Engineering, 86 (2009) 1789-1795

[3] O. Knopfmacher, A. Tarasov, W. Fu, M. Wypf, B. Niesen, M. Calame and C. Schönenberger, "Nernst limit in dual-gated Si-nanowire FET sensors", Nanoletters, 10 (2010) 040802 1-

[4] S. Chen, J.G. Bomer, E.T. Carlen and A. van den Berg, " $\mathrm{Al}_{2} \mathrm{O}_{3} /$ silicon nanoISFET with near ideal Nernstian response", Nanoletters, 11 (2011) 2334-2341 
[5] G. Dingemans and E. Kessels, "Status and prospects of $\mathrm{Al}_{2} \mathrm{O}_{3}$-based surface passivation for silicon solar cells", Journal of Vacuum Science and Technology, A30 (2012) 040802

[6] T. Maindron, B. Aventurier, A. Ghazouani, T. Jullien, N. Rochat, J.Y. Simon and E. Viasnoff, "Investigation of $\mathrm{Al}_{2} \mathrm{O}_{3}$ barrier film properties made by atomic layer deposition onto fluorescent tris-(8-hydroxyquinoline) aluminium molecular films", Thin Solid Films, 548 (2013) 517-525

[7] E.G. Yukihara and S.W.S. Mac Heever, "Optically stimulated luminescence dosimetry in medicine", Physics in Medicine and Biology, 53 (2008) R351-R379

[8] J. Proost and F. Spaegen, "Evolution of the growth stress stiffness and microstructure of alumina thin films during vapour deposition", Journal of Applied Physics, 91 (2004) 204-216

[9] P. Nayar, A. Khanna, D. Kabiraj, S.R. Abhilash, B.D. Beake, Y. Losset and B. Chen, "Structural, optical and mechanical properties of amorphous and crystalline alumina thin films", Thin Solid Films, 568 (2014) 19-24

[10] C. Hibert, H. Hidalgo, C. Champeaux, P. Tristant, C. Tixier, J. Desmaison and A. Catherinot, "Properties of aluminum oxide thin films deposited by pulsed laser deposition and plasma enhanced chemical vapour deposition", Thin Solid Films, 516 (2008) 1290-1296

[11] P.J. Kelly and R.D. Arnell, "Control of the structure and properties of aluminum oxide coating by pulsed magnetron sputtering", Journal of Vacuum Science and Technology, A17 (1999) 945-953

[12] S. Ruppi, "Deposition, microstructure and properties of texture-controlled CVD $\alpha-\mathrm{Al}_{2} \mathrm{O}_{3}$ coatings", International Journal of Refractory Metals and Hard Materials, 23 (2005) 306-316

[13] Q.Y. Shao, A.D. Li, H.Q. Ling, D. Wu, Y. Wang, Y. Feng, S.Z. Yang, Z.G. Liu, M. Wang and N.B. Ming, "Growth and characterization of $\mathrm{Al}_{2} \mathrm{O}_{3}$ gate dielectric films by low-pressure metalorganic chemical vapor deposition", Microelectronic engineering, 66 (2003) 842-848 
[14] R.S. Johnson, G. Lucovski and Isreal Baumvol, "Physical and electrical properties of nanocrystalline prepared by remote plasma enhanced chemical vapour deposition", Journal of Vacuum Science and Technology, A19 (2001) 1353-1360

[15] M. Leskelä and M. Ritala, "Atomic layer deposition (ALD): from precursors to films structures", Thin Solid Films, 409 (2002) 138-146

[16] O. Sneh, R.B. Clark-Phelps, A.R. Londergan, J. Winkler and T.E. Seidel, "Thin film atomic layer deposition equipment for semiconductor processing", Thin Solid Films, 402 (2002) 248261

[17] R.L. Puurunen, "Surface chemistry of atomic layer deposition: a case study for the trimethylaluminum/water process", Journal of Applied Physics, 97 (2005) 121301

[18] A.W. Ott, J.W. Klaus, J.M. Johnson and S.M. George, " $\mathrm{Al}_{2} \mathrm{O}_{3}$ thin film growth on Si (100) using binary sequence chemistry", Thin Solid Films, 292 (1997) 135-144

[19] S.J. Yun, K.H. Lee, J. Skarp, H.R. Kim and K.S. Nam, "Dependence of atomic layerdeposited $\mathrm{Al}_{2} \mathrm{O}_{3}$ films characteristics on growth temperature and $\mathrm{Al}$ precursors of $\mathrm{Al}\left(\mathrm{CH}_{3}\right)_{3}$ and $\mathrm{AlCl}_{3}$ ", Journal of Vacuum Science and Technology, A15 (1997) 2993-2997

[20] R. Matero, A. Rahtu, M. Rittala, M. Leskelä and T. Sajavaara, "Effect of water dose on the atomic layer deposition rate of oxide thin films", Thin Solid Films, 368 (2000) 1-7

[21] J.W. Elam, M.D. Groner and S.M. George, "Viscous flow reactor with quartz microbalance for thin film growth by atomic layer deposition", Review of Scientific Instruments, 73 (2002) $2981-2987$

[22] C. Barbos, D. Blanc-Pelissier, A. Fave, E. Blanquet, A. Crisci, E. Fourmond, D. Albertini, A. Sabac, K. Ayadi, P. Girard and M. Lemiti, "Characterization of $\mathrm{Al}_{2} \mathrm{O}_{3}$ thin films prepared by thermal ALD", Energy Procedia, 77 (2015) 558-564 
[23] P. Borylo, K. Lukaszkowicz, M. Szindler, J. Kubacki, K. Balin, M. Basiaga and J. Szewczenko, "Structure and properties of $\mathrm{Al}_{2} \mathrm{O}_{3}$ thin films deposited by ALD process", Vaccum, 131 (2016) 319-326

[24] S.C. Ha, E. Choi, S.H. Kim and J.S. Roh, "Influence of oxidant source on the property of atomic layer deposited $\mathrm{Al}_{2} \mathrm{O}_{3}$ on hydrogen-terminated Si substrate", Thin Solid Films, 476 (2005) 252-257

[25] J.L. Van Hemmen, S.B.S. Heil, J.H. Klootwijk, F. Roozeboom, C.J. Hodson, M.C.M. van de Sanden and W.M.M. Kessels, "Plasma and thermal ALD of $\mathrm{Al}_{2} \mathrm{O}_{3}$ in a commercial $200 \mathrm{~mm}$ ALD reactor", Journal of the Electrochemical Society, 154 (2007) G165-G169

[26] V.R. Rai, V. Vandalon and S. Agarwal, "Influence of surface temperature on the mechanism of atomic layer deposition of aluminum oxide using an oxygen plasma and ozone", Langmuir, 28 (2012) 350-357

[27] S.E. Potts, H.B. Profikt, R. Roelofs and W.M.M. Kessels, "Room-temperature ALD of metal oxide thin films by energy-enhanced ALD", Chemical Vapor Deposition, 19 (2013) 125-133

[28] L. Aarik, T. Arroval, R. Rammula, H. Mändar, V. Sammelselg, B. Hudec, K. Husekova, K. Fröhlich and J. Aarik, "Atomic layer deposition of high-quality $\mathrm{Al}_{2} \mathrm{O}_{3}$ and $\mathrm{Al}$-doped $\mathrm{TiO}_{2}$ thin films from hydrogen-free precursors", Thin Solid Films, 565 (2014) 19-24

[29] R.L. Puurunen and W. Vandervorst, "Island growth as a growth model in atomic layer deposition: a phenomenological model", Journal of Applied Physics, 96 (2004) 7686-7695

[30] P. Petrik, T. Gumprecht, A. Nutsch, G. Roeder, M. Lemberger, G. Juhasz, O. Polgar, C. Major, P. Kozma, M. Janosov, B. Fodor, E. Agocs and M. Fried, "Comparative measurements on atomic layer deposited $\mathrm{Al}_{2} \mathrm{O}_{3}$ thin films using ex-situ table top and mapping ellipsometry as well as X-ray and VUV reflectometry", Thin Solid Films, 541 (2013) 131-135 
[31] E. Langereis, J. Keijmel, M.C.M. van de Sanden and W.M.M. Kessels, "Surface chemistry of plasma-assisted atomic layer deposition of $\mathrm{Al}_{2} \mathrm{O}_{3}$ studied by infra-red spectroscopy", Applied Physics Letters, 92 (2008) 231904

[32] K.H. Kwon, A. Efremov, S.J. Sun, I. Chun and K. Kim, "Dry etching characteristics of Mo and $\mathrm{Al}_{2} \mathrm{O}_{3}$ films in $\mathrm{O}_{2} / \mathrm{Cl}_{2} / \mathrm{Ar}$ inductively coupled plasmas", Thin Solid Films, 552 (2014) $105-110$

[33] G.G. Stoney, "The tension of metallic films deposited by electrolysis", Proceedings of the Royal Society of London, 9 (1909) 172-175

[34] P. Temple-Boyer, B. Rousset and E. Scheid, "Influences of deposition and crystallization kinetics on the properties of silicon films deposited by chemical vapour deposition from silane and disilane", Thin Solid Films, 518 (2010) 6897-6903

[35] E.D. Palik: "Handbook of optical constant of solids, volume II", Academic press, USA (1998), ISBN: 0-12-544420-6

[36] M. Cho, J. Park, H.-B. Park and C.-S. Hwang, J. Jeong and K.-S. Hyun, "Chemical interaction between atomic-layer-deposited $\mathrm{HfO}_{2}$ thin films and the Si substrate", Applied Physics Letters, 81 (2002) 334-336

[37] Z.-Y. Wang, R.-J. Zhang, H.-L. Lu, X. Chen, Y. Sun, Y. Zhang, Y.-F. Wei, J.-P. Xu, S.-Y. Wang, Y.-X. Zheng and L.-Y. Chen, "The impact of thickness and thermal annealing on refractive index for aluminium oxide thin films deposited by atomic layer deposition", Nanoscale Research Letters, 10 (2015) 46-51

[38] S. Jakschik, U. Schröder, T. Hecht, M. Gutsche, H. Seidl and J.W. Bartha, "Crystallization behaviour of thin $\mathrm{ALD}-\mathrm{Al}_{2} \mathrm{O}_{3}$ films", Thin Solid Films, 425 (2003) 2016-220

[39] G. Krautheim, T. Hecht, S. Jakschik, U. Schröder and W. Zahn, "Mechanical stress in ALD$\mathrm{Al}_{2} \mathrm{O}_{3}$ films", Applied Surface Science, 252 (2005) 200-204 
[40] "Metals, Alloys, Compounds, Ceramics, Polymers, Composites, catalogue 1993/1994", Goodfellow Metals Limited, Cambridge, United Kingdom (1993) 


\section{Tables and figures captions}

Table 1: TEM characterisation of the different structures deposited by PE-ALD from TMA and $\mathrm{O}_{2}$

Table 2: TEM characterisation of the 600-cycle TMA/O 2 PE-ALD $\mathrm{Al}_{2} \mathrm{O}_{3}$ films annealed 5 minutes under an $\mathrm{O}_{2}$ gaseous atmosphere at different temperatures

Table 3: Wet and dry etching properties of $\mathrm{Al}_{2} \mathrm{O}_{3}$ deposited by PE-ALD from TMA and $\mathrm{O}_{2}$

Figure 1: Apparent mean growth rate per ALD cycle and refractive index of $\mathrm{Al}_{2} \mathrm{O}_{3}$ films versus ALD cycle number (parameters were estimated by ellipsometry at a $450 \mathrm{~nm}$ wavelength)

Figure 2: TEM/EDX investigation of the 60-cycle TMA/O 2 PE-ALD sample evidencing a $\mathrm{SiO}_{2} / \mathrm{Al}_{\mathrm{x}} \mathrm{Si}_{\mathrm{y}} \mathrm{O}$ structure: a) TEM image and b) EDX atomic concentration profiles

Figure 3: TEM/EDX investigation of the 600-cycle TMA/O 2 PE-ALD sample evidencing a $\mathrm{Al}_{\mathrm{x}} \mathrm{Si}_{\mathrm{y}} \mathrm{O} / \mathrm{Al}_{2} \mathrm{O}_{3}$ structure: a) TEM image and b) EDX atomic concentration profiles

Figure 4: TEM/EDX investigation of the 300-cycle TMA/O 2 PE-ALD sample deposited on an oxidized ( $\mathrm{SiO}_{2}$ thickness: $\sim 10 \mathrm{~nm}$ ) silicon substrate, evidence of a $\mathrm{SiO}_{2} / \mathrm{Al}_{2} \mathrm{O}_{3}$ steep structure

Figure 5: TEM/EDX investigation of the 600 -cycle TMA/O ${ }_{2} \mathrm{PE}-\mathrm{ALD}$ sample annealed at $750^{\circ} \mathrm{C}$ under an $\mathrm{O}_{2}$ atmosphere, evidence of a $\mathrm{Si} / \mathrm{SiO}_{2} / \mathrm{Al}_{2} \mathrm{O}_{3}$ steep structure 
Figure 6: Refractive index $\mathrm{n}_{450 \mathrm{~nm}}$ of 400-cycle PE- $\mathrm{ALD} \mathrm{Al}_{2} \mathrm{O}_{3}$ films versus annealing temperature (gaseous atmosphere: $\mathrm{N}_{2} / \mathrm{H}_{2}$ and $\mathrm{O}_{2}$ )

Figure 7: XRD investigation of the 400-cycle PE-ALD $\mathrm{Al}_{2} \mathrm{O}_{3}$ sample with annealing temperature:

a) XRD patterns and b) intensity peak height à $67.8^{\circ}$

Figure 8: TEM investigation of the 600-cycle PE-ALD polycrystalline $\mathrm{Al}_{2} \mathrm{O}_{3}$ sample annealed 5 minutes under an $\mathrm{O}_{2}$ gaseous atmosphere at $900^{\circ} \mathrm{C}$

Figure 9: Residual stress $\sigma$ of 900-cycle PE-ALD $\mathrm{Al}_{2} \mathrm{O}_{3}$ films versus annealing temperature (gaseous atmosphere: $\mathrm{N}_{2} / \mathrm{H}_{2}$ and $\mathrm{O}_{2}$ )

Figure 10: Dielectric constant $\varepsilon_{\mathrm{r}}$ of 400 -cycle $\mathrm{PE}-\mathrm{ALD} \mathrm{Al}_{2} \mathrm{O}_{3}$ films versus annealing temperature (gaseous atmosphere: $\mathrm{O}_{2}$ ) 


\begin{tabular}{|c|c|c|c|}
\hline Number of cycles & $\begin{array}{c}\mathrm{SiO}_{2} \text { thickness } \\
(\mathrm{nm})\end{array}$ & $\begin{array}{c}\mathrm{Al}_{\mathrm{x}} \mathrm{Si}_{\mathrm{y}} \mathrm{O} \text { thickness } \\
(\mathrm{nm})\end{array}$ & $\begin{array}{c}\mathrm{Al}_{2} \mathrm{O}_{3} \text { thickness } \\
(\mathrm{nm})\end{array}$ \\
\hline 30 & 4 & 2.5 & 0 \\
\hline 60 & 7 & 5 & 0 \\
\hline 300 & $0 *$ & 6 & 24 \\
\hline 600 & $0 *$ & 6 & 48 \\
\hline $300\left(\right.$ on $\left.\mathrm{SiO}_{2}\right)$ & 10 & $0 *$ & 26 \\
\hline
\end{tabular}

Table 1: TEM characterisation of the different structures deposited by PE-ALD from TMA and $\mathrm{O}_{2}$ (* experimental value lower than the TEM/EDX resolution) 


\begin{tabular}{|c|c|c|c|}
\hline $\begin{array}{c}\text { Annealing } \\
\text { temperature }\end{array}$ & $\begin{array}{c}\mathrm{SiO}_{2} \text { thickness } \\
(\mathrm{nm})\end{array}$ & $\begin{array}{c}\mathrm{Al}_{\mathrm{x}} \mathrm{Si}_{\mathrm{y}} \mathrm{O} \text { thickness } \\
(\mathrm{nm})\end{array}$ & $\begin{array}{c}\mathrm{Al}_{2} \mathrm{O}_{3} \text { thickness } \\
(\mathrm{nm})\end{array}$ \\
\hline as-deposited & $0 *$ & 6 & 48 \\
\hline $750^{\circ} \mathrm{C}$ & 3 & $0 *$ & 52 \\
\hline $900^{\circ} \mathrm{C}$ & 5 & $0 *$ & 47 \\
\hline
\end{tabular}

Table 2: TEM characterisation of the 600-cycle TMA/O 2 PE-ALD $\mathrm{Al}_{2} \mathrm{O}_{3}$ films annealed 5 minutes under an $\mathrm{O}_{2}$ gaseous atmosphere at different temperatures (* experimental value lower than the TEM/EDX resolution) 


\begin{tabular}{|c|c|c|c|c|c|c|}
\hline & \multicolumn{5}{|c|}{ etch rate (nm/min) } \\
\hline & \multicolumn{2}{|c|}{$\begin{array}{c}\text { wet etch } \\
\text { at ambient temperature }\end{array}$} & \multicolumn{3}{c|}{$\begin{array}{c}\mathrm{Cl}_{2} \text { dry etch with bias power } \\
\text { (ICP power: } 500 \mathrm{~W})\end{array}$} \\
\hline & $\begin{array}{c}\mathrm{H}_{3} \mathrm{PO}_{4} \\
85 \%\end{array}$ & $\mathrm{HF} 5 \%$ & $25 \mathrm{~W}$ & $50 \mathrm{~W}$ & $80 \mathrm{~W}$ & $100 \mathrm{~W}$ \\
\hline $\begin{array}{c}\text { amorphous } \\
\mathrm{Al}_{2} \mathrm{O}_{3}\end{array}$ & 0.4 & 40 & 22 & 40 & 70 & 85 \\
\hline $\begin{array}{c}\text { polycrystalline } \\
\mathrm{Al}_{2} \mathrm{O}_{3}\end{array}$ & $\sim 0$ & $\sim 0$ & 20 & 38 & 40 & 40 \\
\hline
\end{tabular}

Table 3: Wet and dry etching properties of $\mathrm{Al}_{2} \mathrm{O}_{3}$ deposited by PE-ALD from TMA and $\mathrm{O}_{2}$ 


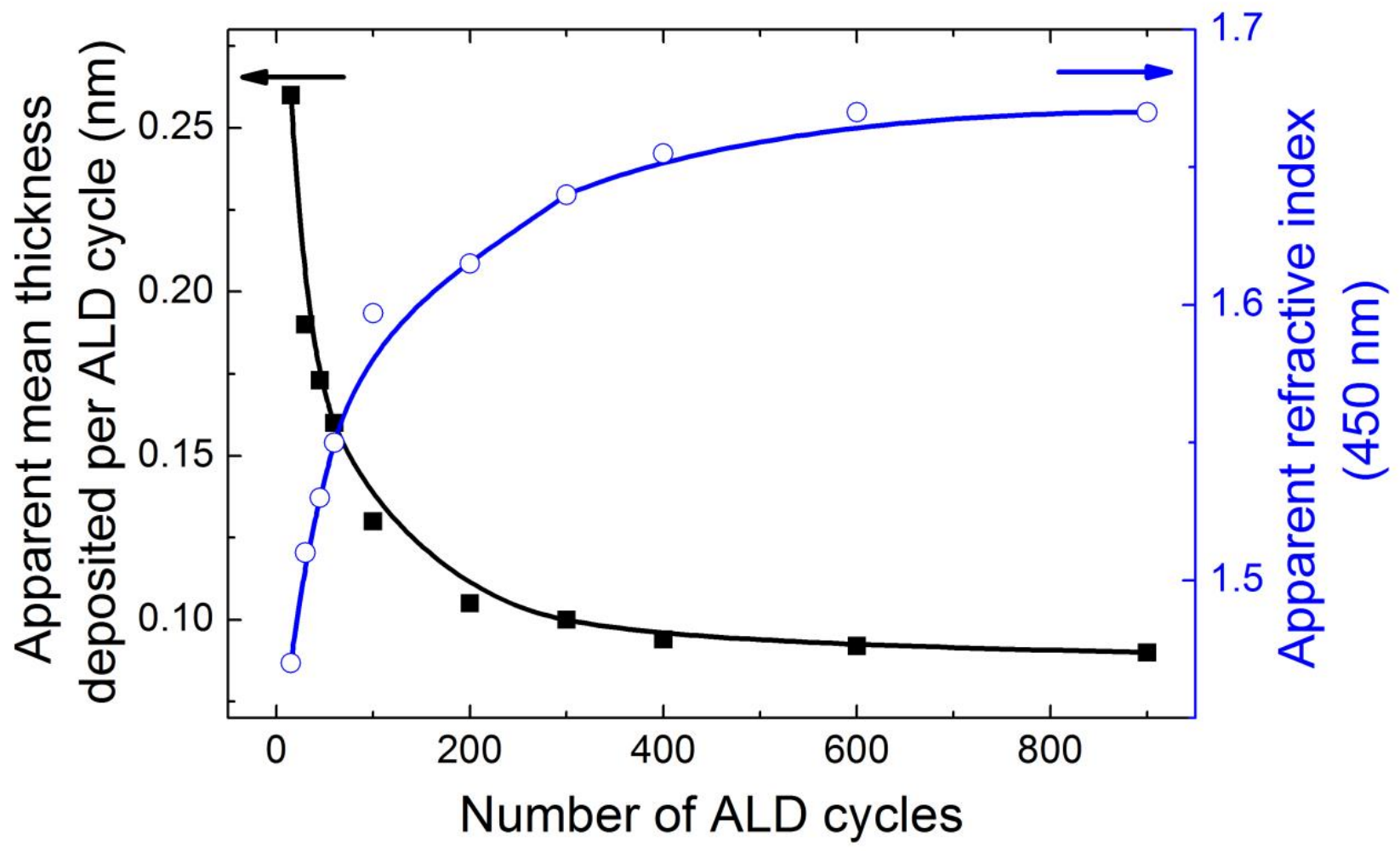

Figure 1: Apparent mean growth rate per ALD cycle and refractive index of $\mathrm{Al}_{2} \mathrm{O}_{3}$ films versus ALD cycle number (parameters were estimated by ellipsometry at a 450nm wavelength) 

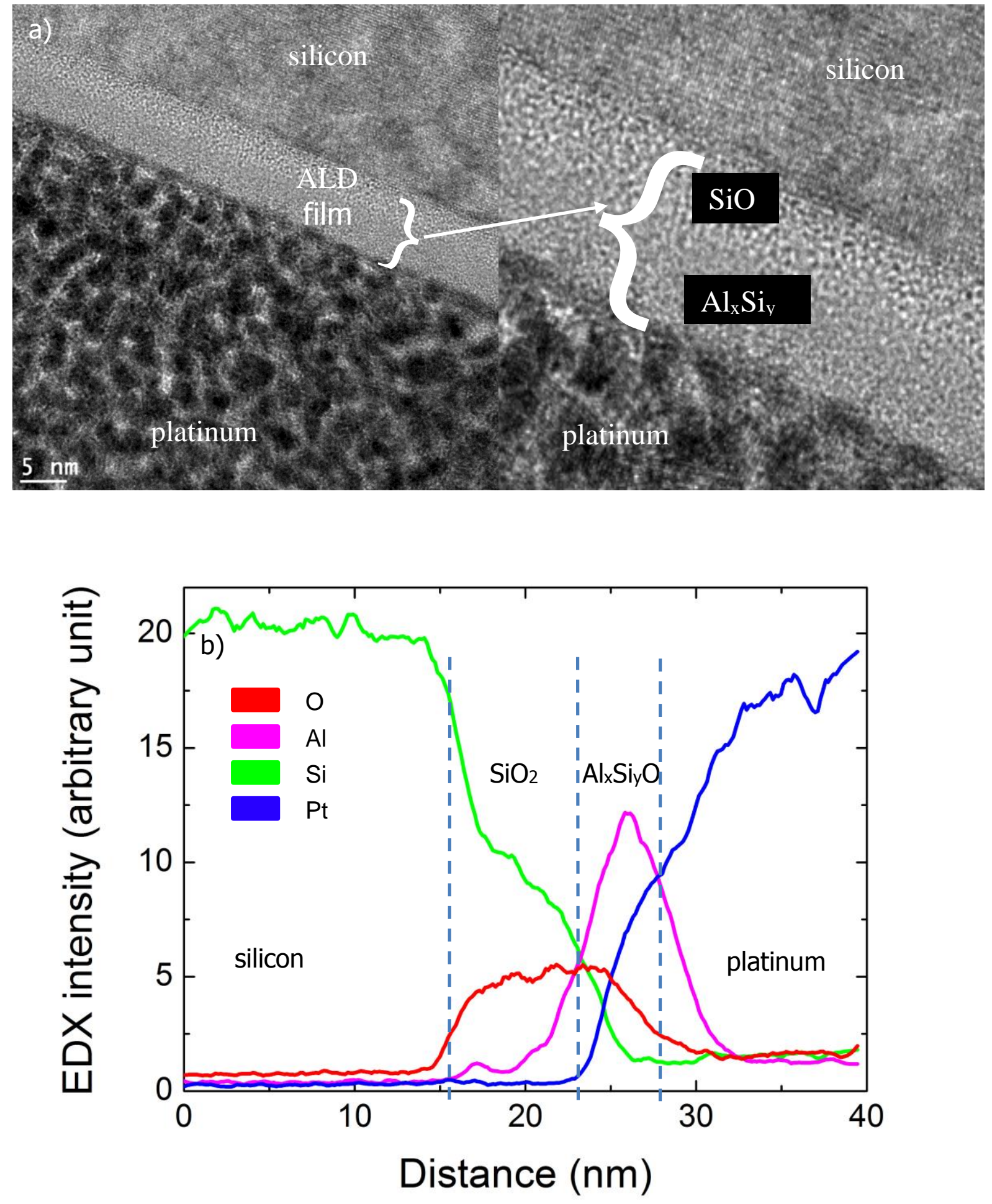

b)

Figure 2: TEM/EDX investigation of the 60-cycle TMA/O 2 PE-ALD sample evidencing an $\mathrm{SiO}_{2} / \mathrm{Al}_{x} \mathrm{Si}_{\mathrm{y}} \mathrm{O}$ structure: a) TEM image and b) EDX atomic concentration profiles 

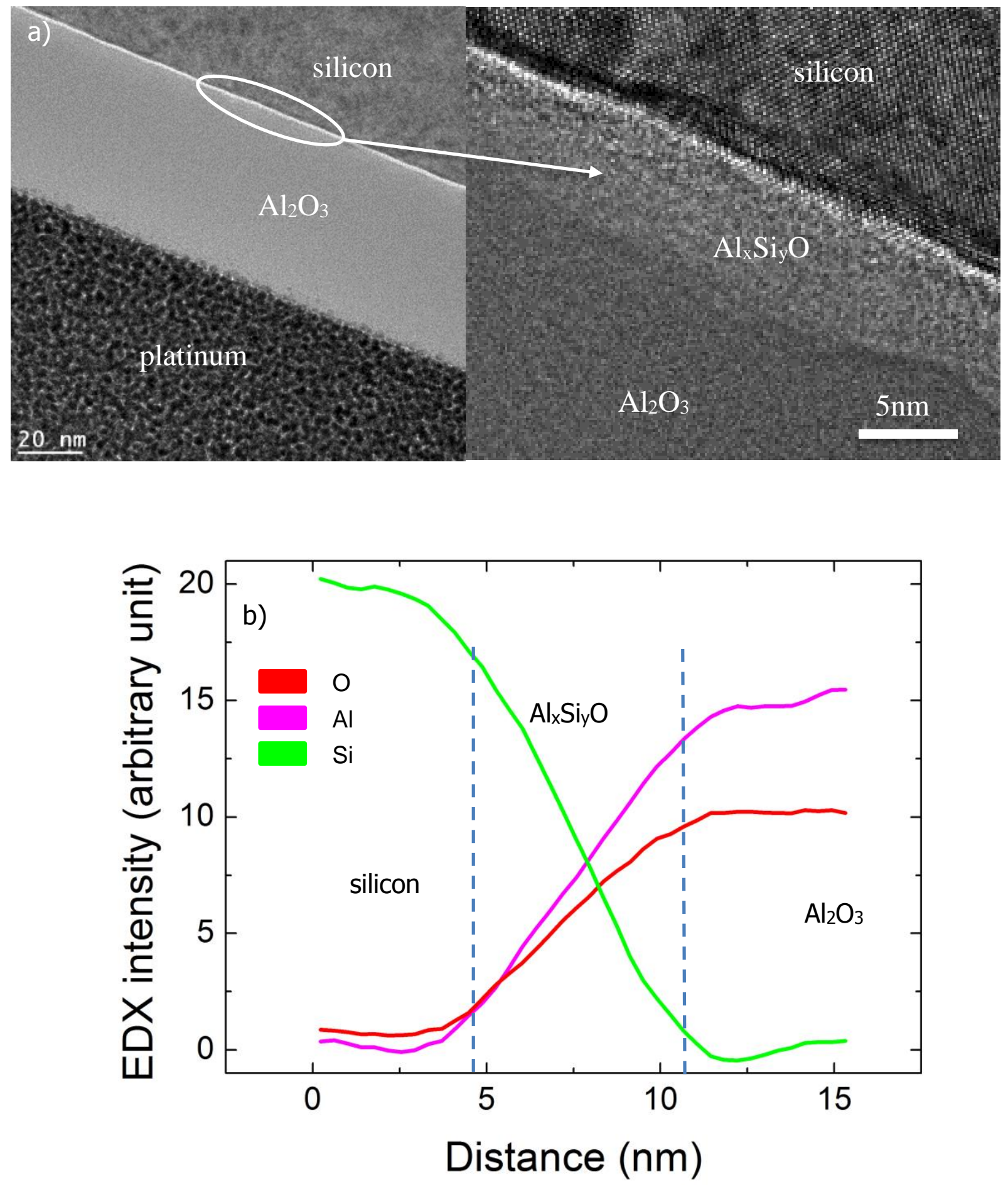

b)

Figure 3: TEM/EDX investigation of the 600-cycle TMA/O 2 PE-ALD sample evidencing an $\mathrm{Al}_{\mathrm{x}} \mathrm{Si}_{\mathrm{y}} \mathrm{O} / \mathrm{Al}_{2} \mathrm{O}_{3}$ structure: a) TEM image and b) EDX atomic concentration profiles 


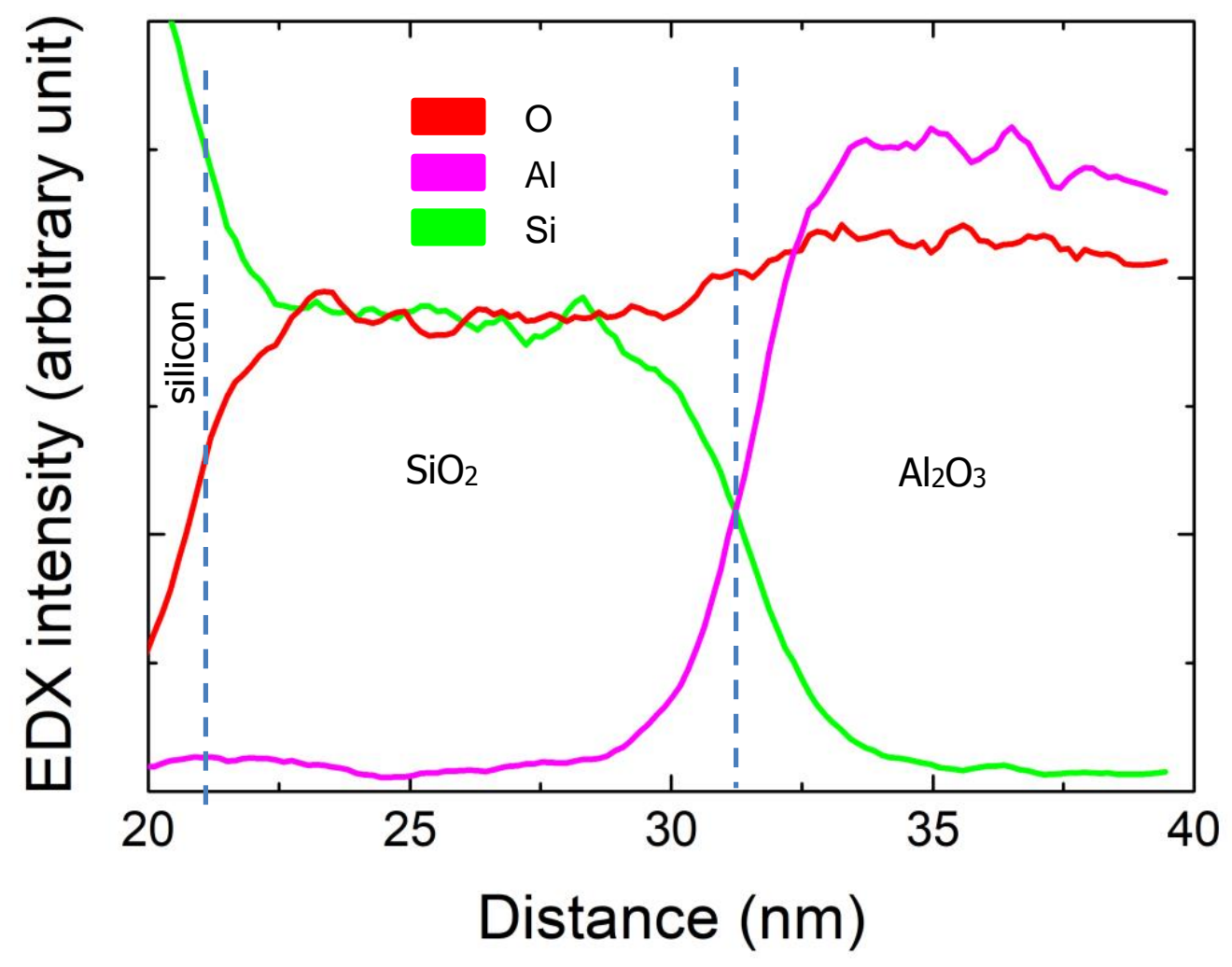

Figure 4: TEM/EDX investigation of the 300-cycle TMA/O 2 PE-ALD sample deposited on an oxidized ( $\mathrm{SiO}_{2}$ thickness: $\sim 10 \mathrm{~nm}$ ) silicon substrate, evidence of a $\mathrm{SiO}_{2} / \mathrm{Al}_{2} \mathrm{O}_{3}$ steep structure 


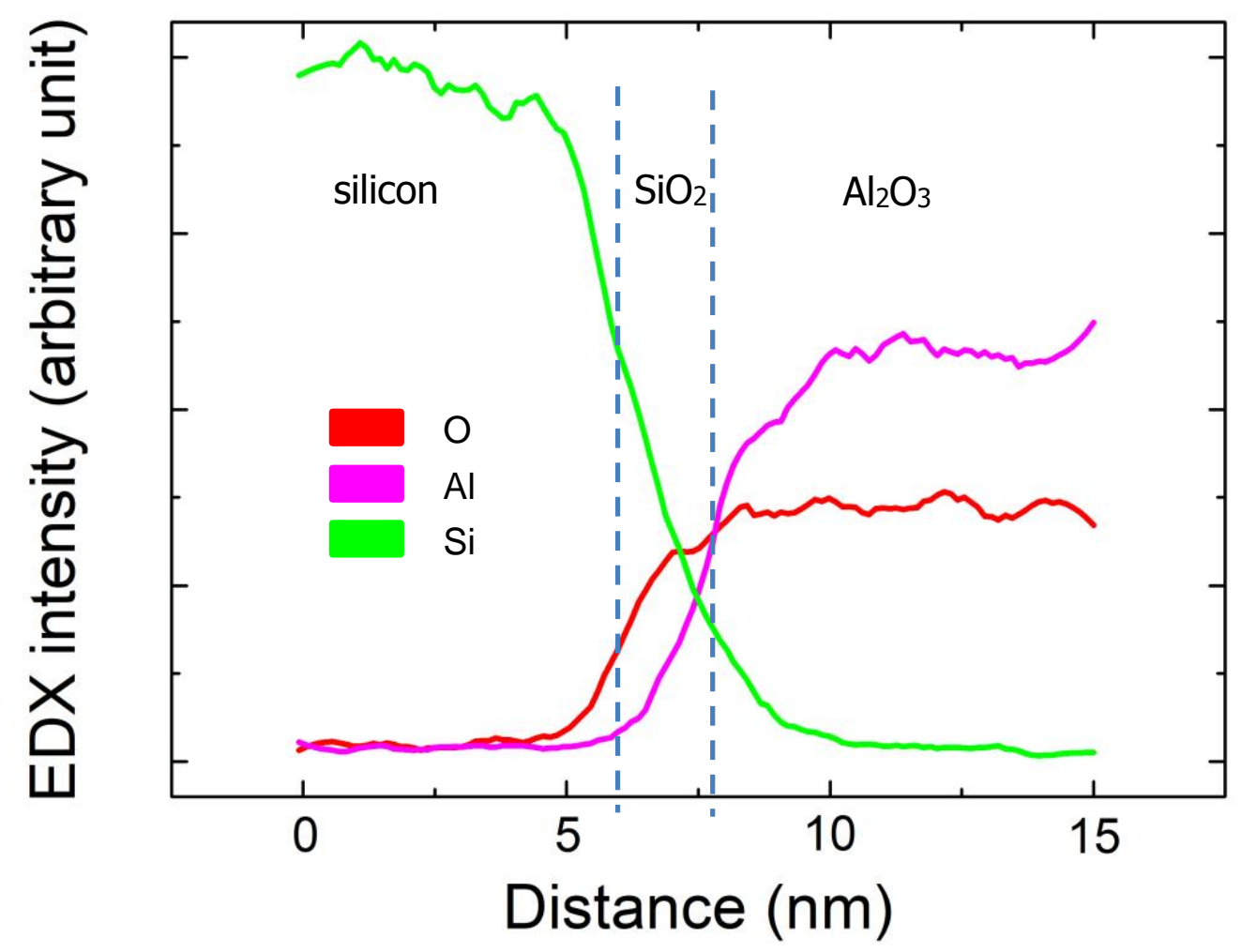

Figure 5: TEM/EDX investigation of the 600 -cycle TMA $/ \mathrm{O}_{2}$ PE-ALD sample annealed at $750^{\circ} \mathrm{C}$ under an $\mathrm{O}_{2}$ atmosphere, evidence of a $\mathrm{Si} / \mathrm{SiO}_{2} / \mathrm{Al}_{2} \mathrm{O}_{3}$ steep structure 


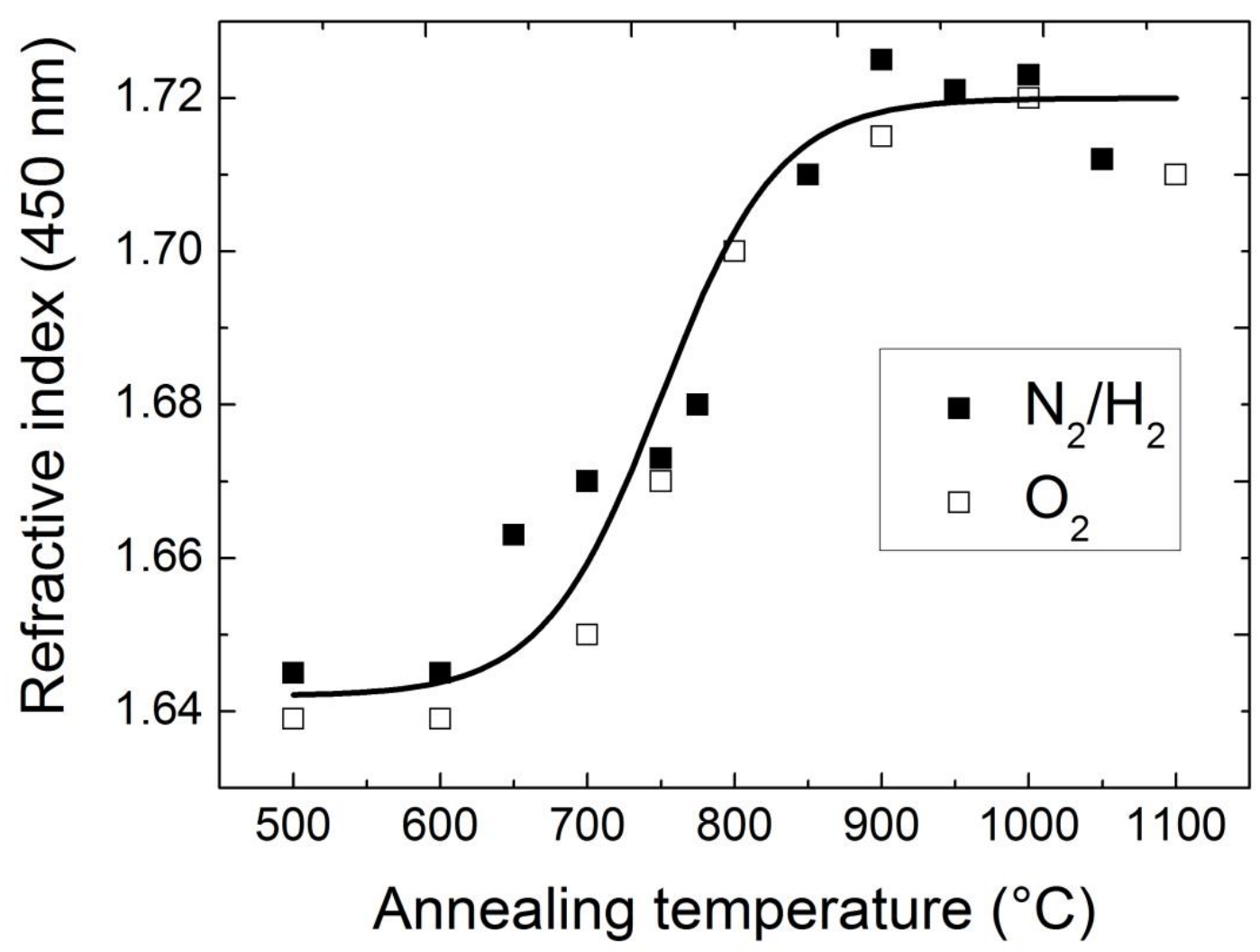

Figure 6: Refractive index n450nm of 400-cycle PE-ALD $\mathrm{Al}_{2} \mathrm{O}_{3}$ films versus annealing temperature (gaseous atmosphere: $\mathrm{N}_{2} / \mathrm{H}_{2}$ and $\mathrm{O}_{2}$ ) 


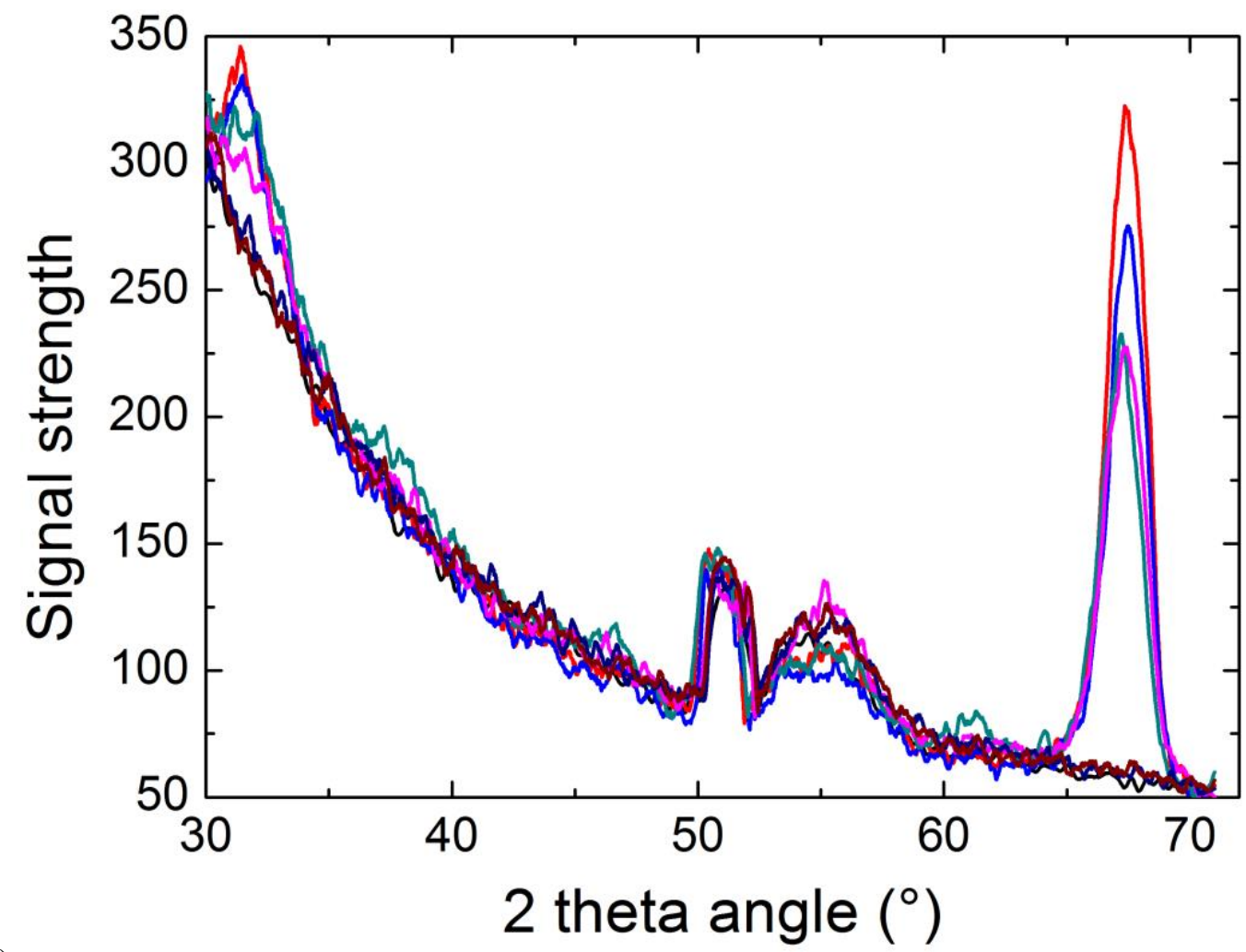

a)

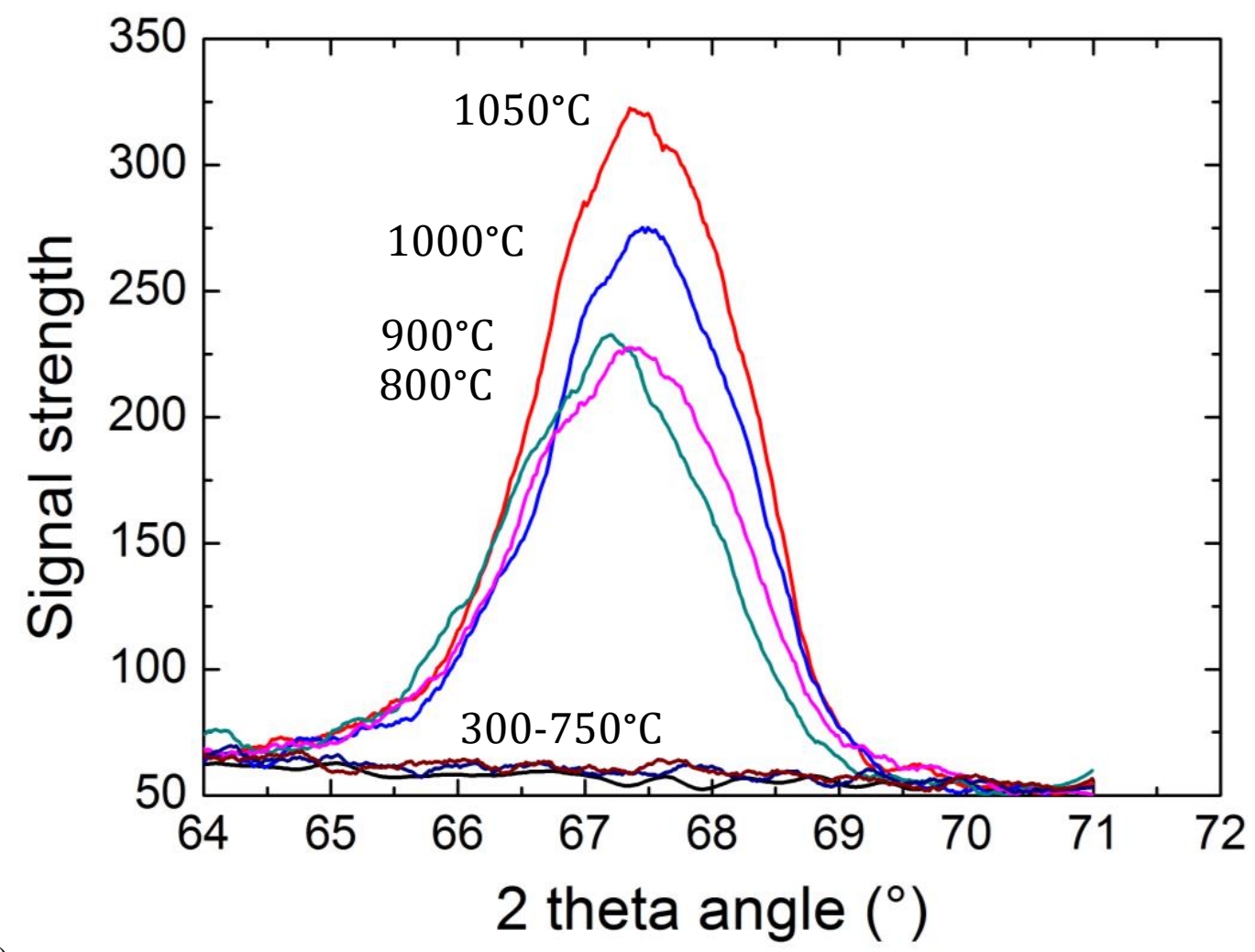

b) 


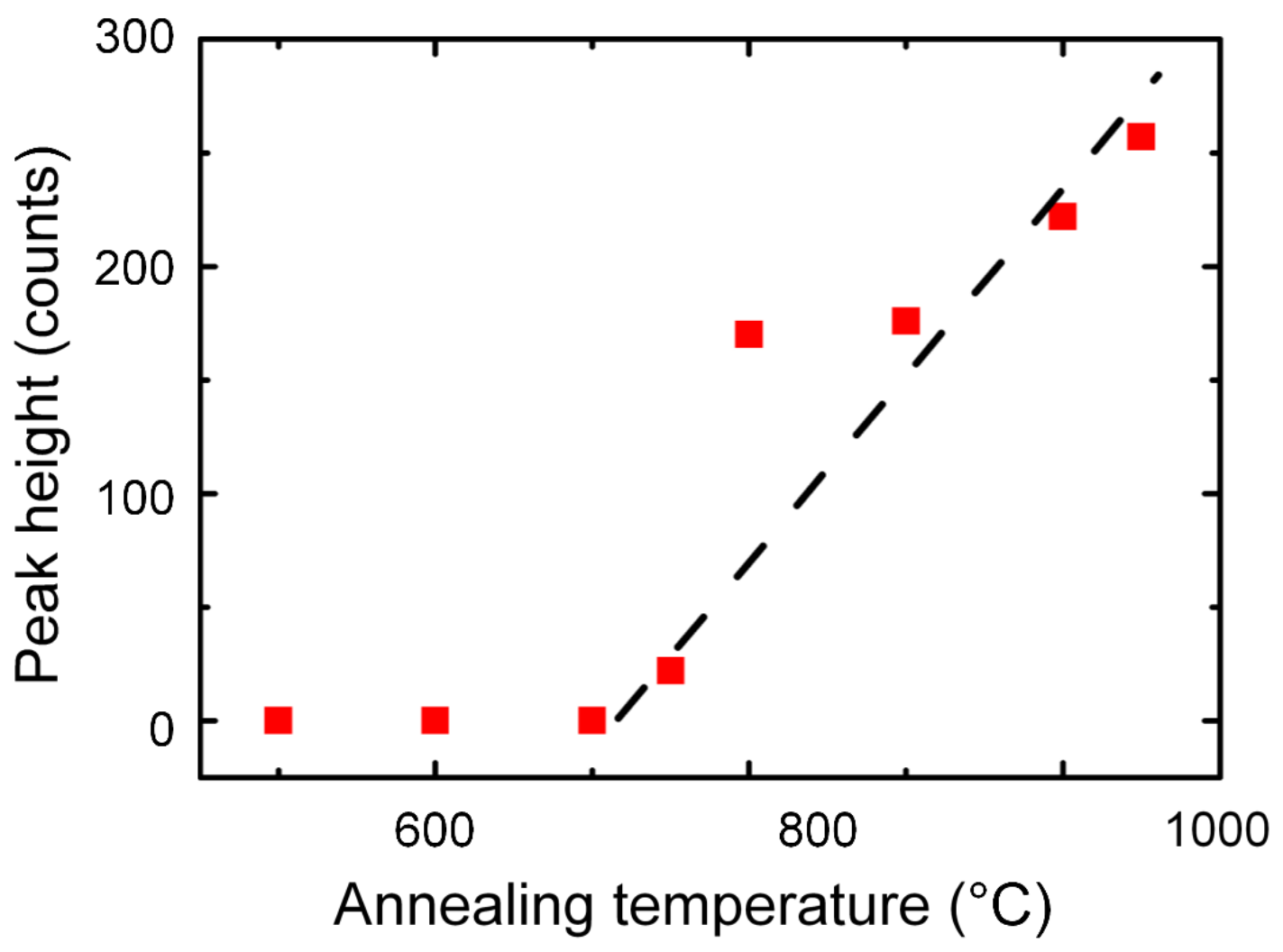

c)

Figure 7: XRD investigation of the 400-cycle PE-ALD $\mathrm{Al}_{2} \mathrm{O}_{3}$ sample with annealing temperature:

a, b) XRD patterns and c) intensity peak height at $67.8^{\circ}$ 


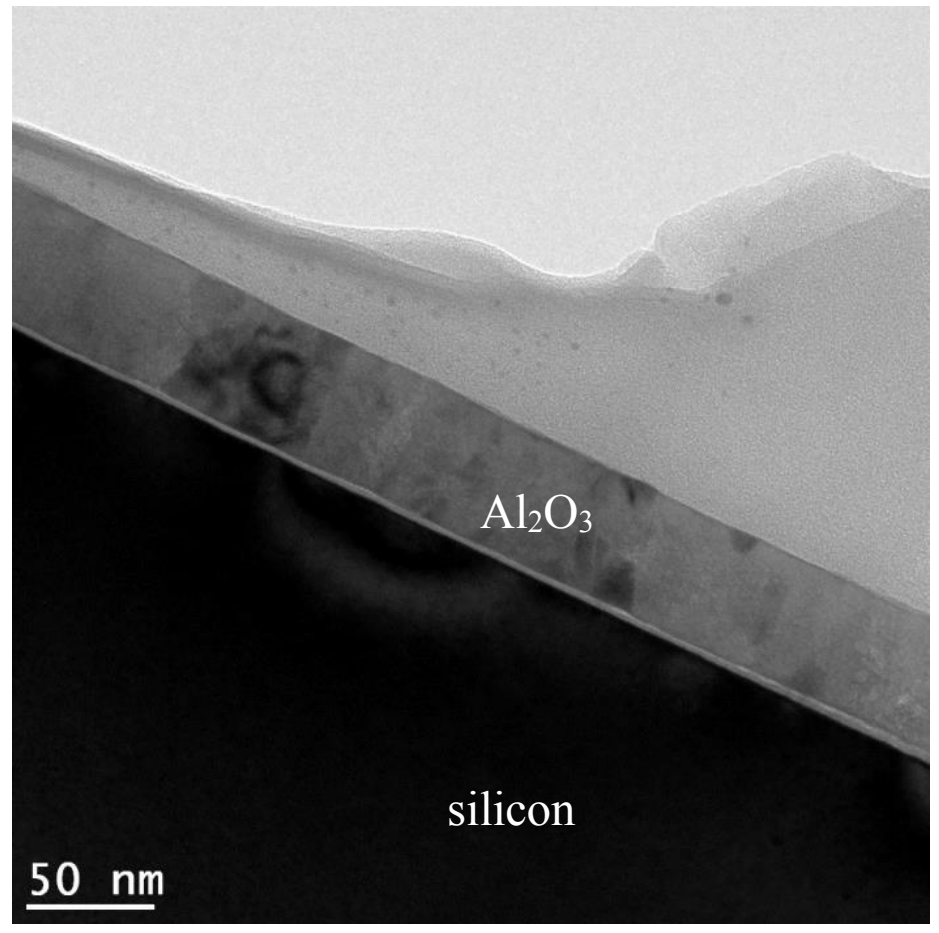

Figure 8: TEM investigation of the 600 -cycle $\mathrm{PE}-\mathrm{ALD}$ polycrystalline $\mathrm{Al}_{2} \mathrm{O}_{3}$ sample annealed 5 minutes under an $\mathrm{O}_{2}$ gaseous atmosphere at $900^{\circ} \mathrm{C}$ 


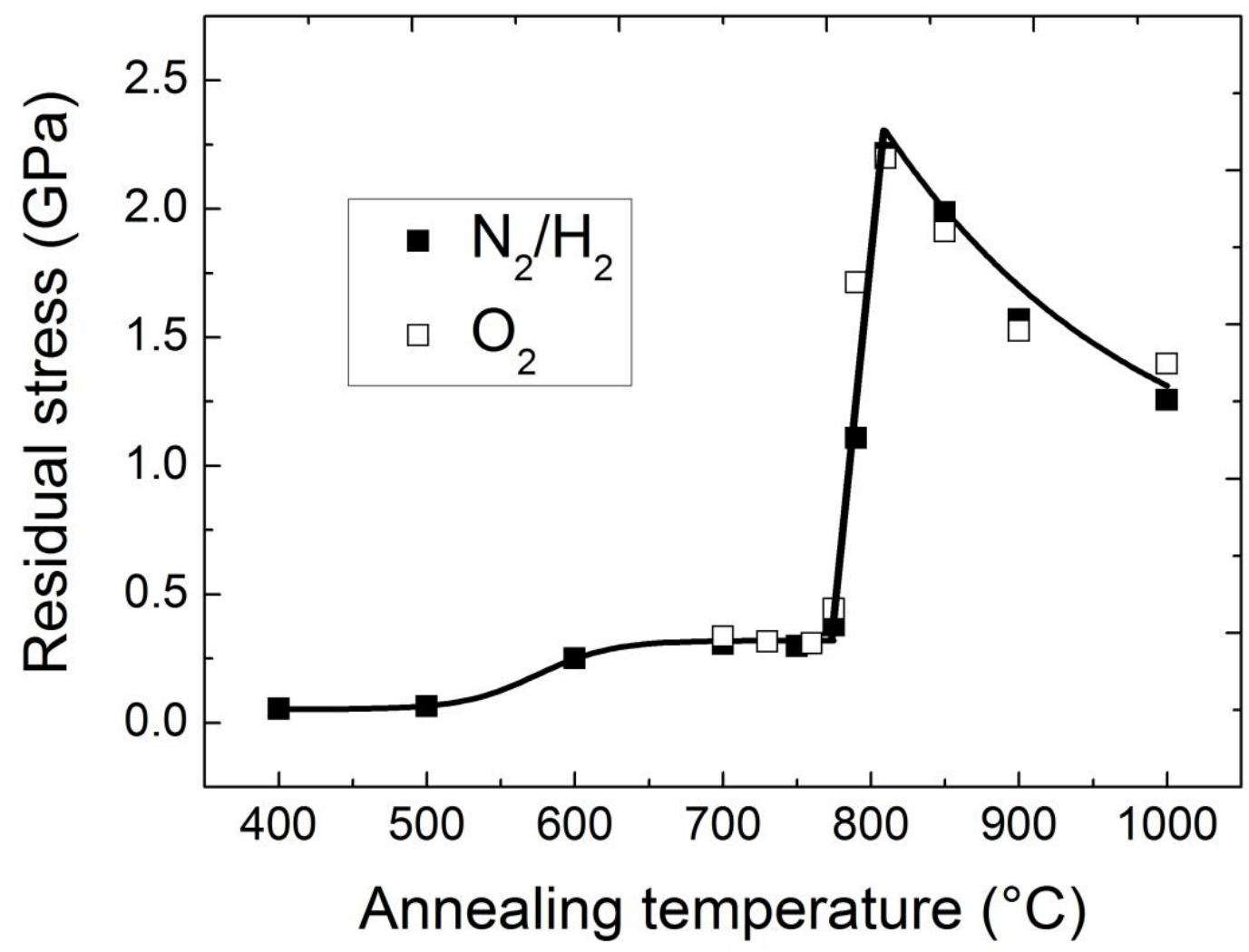

Figure 9: Residual stress $\sigma$ of 900-cycle PE-ALD $\mathrm{Al}_{2} \mathrm{O}_{3}$ films versus annealing temperature (gaseous atmosphere: $\mathrm{N}_{2} / \mathrm{H}_{2}$ and $\mathrm{O}_{2}$ ) 


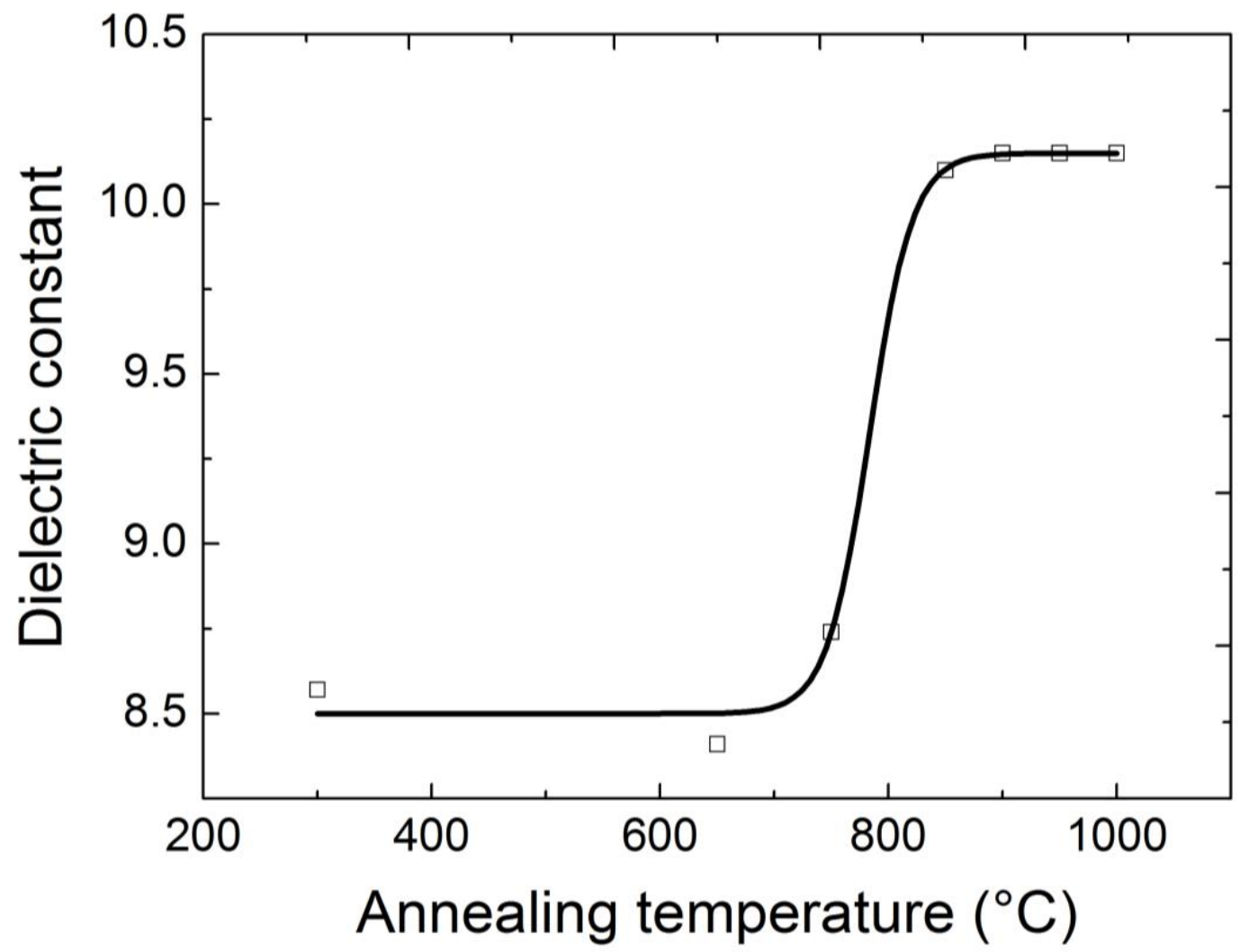

Figure 10: Dielectric constant $\varepsilon_{\mathrm{r}}$ of 400 -cycle PE-ALD $\mathrm{Al}_{2} \mathrm{O}_{3}$ films versus annealing temperature (gaseous atmosphere: $\mathrm{O}_{2}$ ) 